Vol. 3 No. 1 Februari 2019

ISSN 2580-5029

\title{
TOKSISITAS EKSTRAK N-HEKSANA SERBUK GERGAJI KAYU SENGON (Albizia falcataria L. Forberg) TERHADAP MORTALITAS SERANGGA PENGGEREK BUAH KOPI (Hypothenemus hampei Ferr.) (Scolytidae: Coleoptera)
}

\author{
Purwatiningsih $^{1 *}$, Firna Putri Mandasari ${ }^{1}$, Susantin Fajariyah ${ }^{1}$ \\ ${ }^{1}$ Universitas Jember, Jember, Indonesia \\ * purwatiningsih.fmipa@unej.ac.id
}

\begin{abstract}
Research on the toxicity of $n$-hexane extract of Albizia falcataria sawdust against Hypothenemus hampei has been conducted. The method of research was contact method. The concentrations used in the experiment were control (aquadest); 0.25\%; 0.5\%; 1\%; 2\%; and 4\%. Every concentration was sprayed on the female imago. Observations were performed 120 hours after treatment. The results showed that there was an effect of the length of observation time and concentration on the mortality of H. hampei (GLM Test $\alpha=5 \%$ ). The time of observation and concentration of $A$. falcataria sawdust n-hexane extract has positive correlation on $H$. hampei mortality. Therefore, the longer the treatment time, the more $H$. hampei mortality is increased. The mortality of $H$. hampei also increased with increasing concentration given. At a concentration of 4\%, extract of $A$. falcataria sawdust has high toxicity which causes the highest mortality (> 92\%).
\end{abstract}

Keywords: Hypothenemus hampei, Albizia falcataria, Sawdust, N-Hexane, Mortality

\section{ABSTRAK}

Penelitian tentang toksisitas ekstrak n-heksana serbuk gergaji Albizia falcataria terhadap Hypothenemus hampei telah dilakukan. Metode penelitian menggunakan metode racun kontak. Konsentrasi yang digunakan pada uji penelitian yaitu kontrol (aquades); 0,25\%; 0,5\%; 1\%; 2\%; dan $4 \%$. Setiap konsentrasi disemprotkan pada tubuh imago betina. Pengamatan dilakukan selama 120 jam setelah perlakuan. Hasil penelitian menunjukkan bahwa terdapat pengaruh lama waktu pengamatan dan konsentrasi terhadap mortalitas H. hampei (Uji GLM $\alpha=5 \%$ ). Waktu pengamatan dan konsentrasi ekstrak n-heksana serbuk gergaji kayu A. falcataria berbanding lurus terhadap mortalitas $H$. hampei, sehingga semakin lama waktu perlakuan, mortalitas $H$. hampei semakin meningkat. Mortalitas $H$. hampei juga semakin meningkat dengan meningkatnya konsentrasi yang diberikan. Pada konsentrasi 4\%, ekstrak sebuk gergaji kayu A. falcataria memiliki daya racun yang tinggi sehingga menyebabkan kematian tertinggi (> 92\%).

Kata Kunci: Hypothenemus hampei, Albizia falcataria, Serbuk Gergaji, N-Heksana, Mortalitas 


\section{PENDAHULUAN}

Hypothenemus hampei merupakan serangga utama yang menyerang biji kopi. Aktivitas menggerek serangga tersebut menyebabkan penurunan kualitas biji kopi dan produksi hasil panen sampai 30-40\% (Irulandi et al., 2007). Selama ini pengendalian serangga penggerek kopi masih banyak dilakukan dengan insektisida sintetik. Penggunaan insektisida sintetik secara terus menerus dapat menurunkan kualitas biji kopi dan mengakibatkan resistensi serangga (Wiryadiputra, 2012). Salah satu alternatif pengendalian hama yang dapat digunakan adalah menggunakan insektisida nabati yang bahan utamanya dari tumbuhan (Dadang \& Prijono, 2011). Salah satu tumbuhan yang berpotensi sebagai insektisida nabati adalah sengon (Albizia falcataria).

Sengon termasuk tanaman jenis kayu yang saat ini banyak dimanfaatkan sebagai furniture, molding, boxes, craft, dan pulp feedstock (Krisnawati et al., 2011). Salah satu limbah yang dihasilkan dari industri furniture sengon adalah serbuk gergaji. Sampai saat ini serbuk gergaji masih belum banyak dimanfaatkan.

Genus Albizia mengandung senyawa metabolit sekunder antara lain alkaloid, glikosida, terpenoid, steroid, saponin, dan antrakuinin (Hussain et al., 2016). Senyawa metabolit sekunder Albizia memiliki aktivitas insektisida. Serbuk gergaji kayu A. falcataria mengandung senyawa metabolit sekunder yaitu falvonoid, saponin, alkaloid, steroid dan triterpen (King et al., 2013). Kulit kayu A. chinensis dilaporkan mengandung triterpen dan saponin (Liu et al., 2009). Menurut Schummuterer (1999), senyawa triterpenoid dapat bersifat toksik pada lalat buah (Bactrocera spp.). Ekstrak kulit kayu $A$. odoratissima memiliki efek insektisida terhadap larva hama kubis Pieris brassicae (Sinha, 2012).

Setiap tanaman memiliki karakter senyawa metabolit sekunder yang berbeda. Karakter senyawa-senyawa metabolit sekunder memiliki tingkat kepolaran yang berbeda. Untuk memaksimalkan penarikan senyawa aktif pada tanaman harus mempertimbangkan sifat kepolarannya (Asmaliyah et al., 2010). Senyawa polar akan mudah larut pada pelarut yang bersifat polar seperti metanol dan etanol, sedangkan senyawa nonpolar juga akan mudah larut pada pelarut yang bersifat nonpolar seperti n-heksana. Berdasarkan penelitian King et al., (2013), serbuk gergaji kayu A. falcataria mengandung senyawa polar yang berbeda dibandingkan senyawa nonpolar. Oleh karena itu, pada penelitian ini dilakukan uji toksisitas ekstrak n-heksana (nonpolar) serbuk gergaji kayu sengon terhadap mortalitas H. hampei.

\section{METODE}

\section{Tempat dan Waktu Penelitian}

Penelitian ini dilaksanakan di Laboratorium Zoologi Jurusan Biologi Fakultas Matematika dan Ilmu Pengetahuan 
Alam, Universitas Jember. Penelitian pada bulan April sampai Juni 2018.

\section{Alat dan Bahan}

Alat yang digunakan dalam penelitian ini adalah saringan, pipet tetes, beaker glass $150 \mathrm{ml}$, kuas, gelas ukur $10 \mathrm{ml}$, kain, pinset, cutter, kapas, benang wol, timbangan, penggaris, alat soxhlet, oven, rotary evaporator BÜCHI, erlenmeyer, cup plastik ( $\mathrm{d}=4 \mathrm{~cm}, \mathrm{t}=4 \mathrm{~cm})$, corong, mikroskop, mikropipet, karet gelang dan labu pengencer $10 \mathrm{ml}$.

Bahan yang digunakan dalam penelitian ini adalah imago betina H. hampei, biji kopi, serbuk gergaji kayu sengon yang diperoleh dari penggergajian kayu, larutan nheksana teknis, kertas saring, tween 80, aquades dan label.

\section{Prosedur Penelitian}

Penelitian ini menggunakan Rancangan Acak Lengkap (RAL) dengan 6 perlakuan dan masing-masing perlakuan dengan 10 pengulangan. Konsentrasi yang digunakan adalah Kontrol (aquades); 0,25\%; 0,5\%; 1\%; 2\%; dan 4\%. Masing-masing konsentrasi diaplikasikan dengan metode kontak pada 10 imago betina $H$. hampei. Pengamatan kematian serangga uji dilakukan sampai 120 jam.

\section{Ekstraksi Serbuk Gergaji A. falcataria}

Sampel serbuk gergaji A. falcataria yang telah diperoleh dari penggergajian dikeringkan menggunakan oven pada temperatur $50^{\circ} \mathrm{C}$ selama 48 jam. Serbuk gergaji kasar yang sudah di oven, disaring menggunakan ayakan ukuran 7 mesh $( \pm 2,8$ $\mathrm{mm}$ ) sehingga dihasilkan serbuk gergaji yang halus. Serbuk gergaji halus ditimbang seberat 280 gram, kemudian serbuk gergaji dibungkus dengan kertas saring masingmasing seberat 10 gram dan 5 gram. Proses ekstraksi menggunakan pelarut n-heksana dilakukan selama 1 minggu menggunakan alat soxhlet. Ekstraksi dilakukan secara periodik sampai semua serbuk gergaji yang sudah ditimbang habis diekstrak. Pemanasan dilakukan secara paralel dengan menyusun 6 tabung soxhlet. Tabung soxhlet yang digunakan memiliki 2 jenis ukuran yang berbeda yaitu 1 tabung soxhlet besar dan 5 tabung soxhlet kecil. Pada tabung soxhlet besar dimasukkan 10 gram serbuk gergaji sejumlah 8 bungkus, sedangkan pada 5 tabung soxhlet kecil dimasukkan 5 gram serbuk gergaji sejumlah 40 bungkus. Tabung dengan ukuran yang besar, dimasukkan 10 gram serbuk gergaji dengan $250 \mathrm{ml}$ pelarut $\mathrm{n}$ heksana, sedangkan 5 tabung yang memiliki ukuran kecil dan dimasukkan 5 gram serbuk gergaji dengan $150 \mathrm{ml}$ pelarut n-heksana.

Proses pemanasan dengan soxhlet tersebut dilakukan pada suhu $\pm 65^{\circ} \mathrm{C}$ selama 2-3 jam, yang menghasilkan 15-20 siklus putaran per tabung. Ekstraksi dihentikan apabila pelarut n-heksana sudah berwarna jernih. Ekstrak cair n-heksana yang dihasilkan disaring menggunakan corong dan kertas saring untuk memisahkan serbuk 
gergaji yang ikut larut di dalam pelarut. Total hasil ekstrak n-heksana dari ekstraksi adalah 1,7 L, ekstrak tersebut kemudian diuapkan menggunakan rotary evaporator BÜCHI selama 4 jam 30 menit pada suhu $\pm 50^{\circ}-60^{\circ} \mathrm{C}$. hasil akhir didapatkan pasta seberat 4 gram berwarna kuning pucat. Ekstrak pasta yang diperoleh tersebut digunakan sebagai bahan uji.

\section{Pelaksanaan Penelitian}

Metode yang digunakan dalam penelitian ini adalah metode kontak (Prijono, 1988). Ekstrak n-heksana sebanyak 0,1 ml dicampur dengan tween 80 dan aquades untuk membuat larutan stok (8\%). Konsentrasi yang digunakan untuk uji penelitian yaitu kontrol (aquades); 0,25\%; 0,5\%; 1\%; 2\% dan 4\%. Pada tiap konsentrasi yang berbeda, serangga betina dewasa $H$. hampei sebanyak 10 ekor dimasukkan ke dalam cup plastik $(\mathrm{d}=4 \mathrm{~cm}, \mathrm{t}=4 \mathrm{~cm})$ yang sudah diberi alas kertas saring. Selanjutnya dilakukan penyemprotan menggunakan hand sprayer sampai mengenai seluruh tubuh serangga uji. Jika ada pelarut yang berlebih maka dibersihkan dengan kertas tissu. Cup berisi $H$. hampei ditutup penutup plastik yang sudah dilubangi terlebih dahulu. Setiap perlakuan dilakukan 10 kali ulangan.

Pengamatan dilakukan dengan menghitung persentase mortalitas $H$. hampei. Pengamatan dilakukan setiap 24 jam sampai jam ke 120. Pada pengamatan mortalitas 24 jam pertama, kertas saring yang digunakan sebagai alas diganti dengan kertas saring yang baru dan serangga uji diberi pakan. Serangga uji dinyatakan mati apabila tubuh serangga sudah tidak bergerak jika disentuh dengan kuas. Pengamatan gerakan tubuh $H$. hampei dilakukan menggunakan mikroskop stereo.

\section{HASIL DAN PEMBAHASAN}

Toksisitas Ekstrak N-heksana Serbuk Gergaji $A$. falcataria terhadap Mortalitas

\section{H. hampei}

Hasil uji statistik menggunakan General Linear Model (GLM) Multivariate Tests menunjukkan bahwa terdapat pengaruh ekstrak n-heksana serbuk gergaji kayu $A$. falcataria terhadap kematian $H$. hampei ( $\mathrm{F}=67.804, \mathrm{p}$ 0,000). Berdasarkan hasil dari Multivariate Tests menunjukkan adanya dua hasil, yaitu pengaruh waktu perlakuan dengan mortalitas H. hampei dan pengaruh waktu dan konsentrasi ekstrak serbuk gergaji A. falcataria terhadap mortalitas $H$. hampei. Pada pengaruh perlakuan hari (waktu) terhadap mortalitas $H$. hampei menunjukkan bahwa pada tes Pillai's Trace,Wilks' Lambda, Hotelling's Trace dan Roy's Largest Root memiliki nilai $F_{\text {tabel }}$ sebesar 1,210 dengan signifikasi dibawah 0,05 sehingga hari (waktu) perlakuan berpengaruh terhadap mortalitas H. hampei.

Hasil kedua yaitu pengaruh hari (waktu) dan konsentrasi ekstrak terhadap mortalitas $H$. hampei ditunjukkan pada tes Pillai's Trace $(\mathrm{F}=4,010 ; \mathrm{P}=0,00<0,05)$, tes 
Wilks' Lambda (F=6,117; $\mathrm{P}=0,00<0,05)$, tes

Hotelling's Trace $(\mathrm{F}=8,961 ; \mathrm{P}=0,00<0,05)$, dan Roy's Largest Root (F=34,755; $\mathrm{P}=0,00<0,05)$ yang menunjukkan bahwa hari (waktu) dan konsentrasi ekstrak yang diberikan berpengaruh terhadap mortalitas $H$. hampei. Konsentrasi ekstrak n-heksana serbuk gergaji kayu A. falcataria dengan waktu pengamatan berbanding lurus terhadap mortalitas $H$. hampei, sehingga semakin lama waktu perlakuan, mortalitas H. hampei semakin meningkat. Mortalitas H. hampei juga semakin meningkat dengan meningkatnya konsentrasi yang diberikan (Gambar 1).

Mortalitas H. hampei setelah perlakuan 120 jam menunjukkan, kematian paling rendah teramati pada konsentrasi $0,25 \%$ (24\%), sedangkan kematian yang paling tinggi konsentrasi 4\% (92\%).

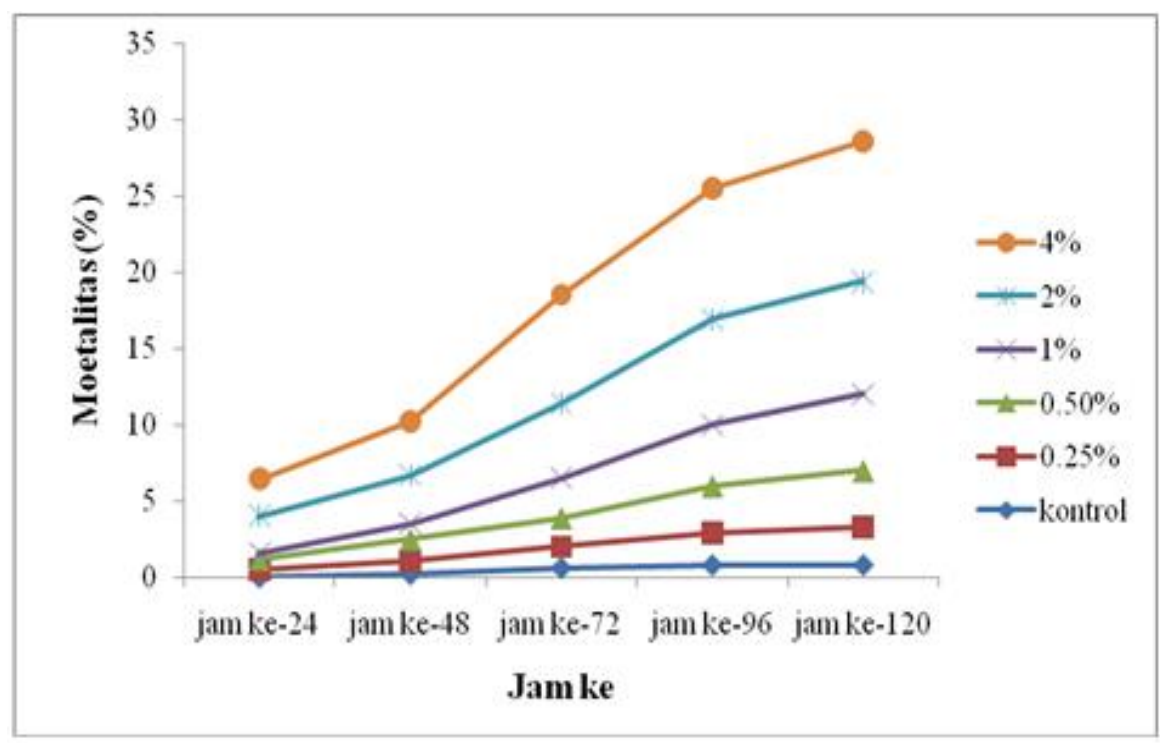

Gambar 1. Mortalitas H. hampei Setelah Perlakuan Ekstrak N-heksana Serbuk Gergaji Kayu A. falcataria.

Hasil uji lanjut Duncan $(\alpha=5 \%)$ perbedaan yang nyata antar konsentrasi menunjukkan bahwa kematian serangga uji pada jam ke-24 dan jam ke-48 pada dengan kontrol kecuali pada konsentrasi konsentrasi $0,25 \% ; \quad 0,5 \%$ dan $1 \%$ tidak berbeda nyata dengan kontrol, sedangkan pada konsentrasi $2 \%$ dan $4 \%$ berbeda nyata dengan kontrol. Pengamatan kematian $0,25 \%$. Kematian serangga uji pada jam ke-96 dan jam ke-120 menunjukkan perbedaan yang nyata antar konsentrasi dengan persentase kematian $86 \%$ dan $92 \%$ pada konsentrasi 4\% (Tabel 1) serangga uji pada jam ke-72 menunjukkan 
Biotropic 2019 Vol. 3 (1): 39 - 48

Toksisitas Ekstrak n-heksana Serbuk Gergaji Kayu Sengon (Albizia falcataria L. Forberg) terhadap Mortalitas Serangga Penggerek Buah Kopi (Hypothenemus hampei Ferr.) (Scolytidae: Coleoptera)

Tabel 1. Mortalitas H. hampei Setelah Perlakuan Ekstrak N-heksana Serbuk Gergaji Kayu A. falcataria $(\mathrm{n}=10)$.

\begin{tabular}{cccccc}
\hline \multirow{2}{*}{ Perlakuan } & \multicolumn{5}{c}{ \% Mortalitas (Rata-rata \pm SD) } \\
\cline { 2 - 6 } & Jam ke-24 & Jam ke-48 & Jam ke-72 & Jam ke-96 & Jam ke-120 \\
\hline Kontrol/Aquadest & $0 \pm 0,00^{\mathrm{a}}$ & $2 \pm 4,22^{\mathrm{a}}$ & $6 \pm 6,99^{\mathrm{a}}$ & $8 \pm 7,89^{\mathrm{a}}$ & $9 \pm 8,76^{\mathrm{a}}$ \\
$\mathbf{0 , 2 5 \%}$ & $6 \pm 6,99^{\mathrm{a}}$ & $9 \pm 11,01^{\mathrm{a}}$ & $14 \pm 9,66^{\mathrm{a}}$ & $21 \pm 5,68^{\mathrm{b}}$ & $24 \pm 8,43^{\mathrm{b}}$ \\
$\mathbf{0 , 5 0 \%}$ & $7 \pm 8,23^{\mathrm{a}}$ & $14 \pm 10,7^{\mathrm{a}}$ & $19 \pm 11,97^{\mathrm{b}}$ & $31 \pm 7,38^{\mathrm{c}}$ & $37 \pm 6,7^{\mathrm{c}}$ \\
$\mathbf{1 \%}$ & $4 \pm 5,16^{\mathrm{a}}$ & $10 \pm 9,43^{\mathrm{a}}$ & $26 \pm 8,43^{\mathrm{c}}$ & $40 \pm 8,16^{\mathrm{d}}$ & $50 \pm 10,54^{\mathrm{d}}$ \\
$\mathbf{2 \%}$ & $24 \pm 11,74^{\mathrm{b}}$ & $33 \pm 14,94^{\mathrm{b}}$ & $49 \pm 8,76^{\mathrm{d}}$ & $69 \pm 7,38^{\mathrm{e}}$ & $74 \pm 8,43^{\mathrm{e}}$ \\
$\mathbf{4 \%}$ & $24 \pm 24,59^{\mathrm{b}}$ & $35 \pm 19,0^{\mathrm{b}}$ & $71 \pm 16,63^{\mathrm{e}}$ & $86 \pm 13,50^{\mathrm{f}}$ & $92 \pm 9,19^{\mathrm{f}}$ \\
\hline
\end{tabular}

Keterangan: huruf superscrip yang berbeda pada kolom yang sama menunjukkan nilai yang berbeda nyata (Uji Duncan $\alpha=5 \%$ ).

Pada penelitian ini ekstrak n-heksana serbuk gergaji $A$. falcataria menyebabkan peningkatan kematian serangga uji yang tinggi dengan semakin besarnya konsentrasi yang diaplikasikan. Mortalitas tertinggi ditunjukkan pada konsentrasi 4\% (92\%) dan konsentrasi terendah 0,25\% (24\%). Hal ini diduga karena adanya kandungan senyawa aktif bersifat insektisida pada ekstrak tersebut. Pada genus yang sama yaitu $A$. falcataria mengandung terpenoid dan steroid (King et al., 2013). Terpenoid dan steroid merupakan senyawa yang memiliki potensi sebagai insektisida. Hal ini sesuai dengan penelitian Aini (2018), ekstrak nheksana kulit batang Rhizopora mucronata yang mengandung terpenoid dengan pengaplikasian metode racun kontak pada $H$. hampei dengan konsentrasi 1\% diperoleh nilai $\mathrm{LC}_{50}$ adalah $79 \%$. Penelitian lain yaitu Bahri \& Rinawati (2005), menjelaskan fraksi $\mathrm{CHCl}_{3}$ (kloroform) dan daun lada (Piper nigrum) mengandung senyawa terpenoid yang menyebabkan kematian terhadap Callosobrunus chinensis.

Terpenoid bersifat sebagai penolak serangga (repellent) karena memiliki bau menyengat yang tidak disukai serangga. Senyawa ini dapat mempengaruhi fungsi saraf dan menghambat enzim asetilkolinesterase (AchE) yang menyebabkan gangguan transmisi rangsang, menurunkan kerja otot, dan kematian pada serangga (Rattan, 2010; Rohmawati, 2015).

Senyawa metabolit sekunder pada ekstrak n-heksana serbuk gergaji A. falcataria yang lain juga diduga mengakibatkan kematian terhadap serangga uji. Menurut penelitian Adirestuti et al., (2014); Rastuti \& Purwati (2012), daun A. falcataria mengandung senyawa metabolit sekunder yaitu saponin, flavonoid, fenolat, kuinon dan steroid-triterpenoid yang terdapat di dalam fraksi etanol atau fraksi n-heksana. Keberadaan senyawa terpenoid dan steroid diduga juga terdapat pada serbuk gergaji $A$. falcataria dengan konsentrasi yang berbeda. 
Saponin merupakan glikosida amphiatik yang memiliki sifat mirip deterjen. Saponin memiliki efek menurunkan tegangan permukaan kulit sehingga dapat merusak permukaan kulit. Sifat yang seperti deterjen dapat mengganggu lapisan lipid dari epikutikula dan mengganggu lapisan protein endokutikula, sehingga senyawa toksik dapat masuk ke dalam tubuh (Tarumingkeng, 1992). Senyawa saponin juga dapat mematikan serangga karena mampu menyebabkan hemolisis sel-sel darah merah (Chaib, 2010; Francis et al., 2002). Senyawa saponin pada daun dan bunga Ageratum conyzoides bersifat insektisida yang menyebabkan mortalitas Sitophilus spp. (Astriani, 2010).

Senyawa steroid merupakan senyawa yang mamiliki sifat toksik terhadap serangga. Menurut Hopkins \& Huner (2004), senyawa steroid yang terdapat pada tumbuhan memiliki fungsi protektif, seperti fitoekdison yang dapat menghambat proses molting pada serangga. Menurut Yunita et al., (2009), senyawa steroid memiliki efek yang dapat menghambat perkembangan nyamuk Aedes aegypti.

Penelitian Istimuyasaroh et al., (2009) menyatakan bahwa insektisida selain bekerja sebagai racun kontak dan racun perut secara tidak langsung juga bersifat sebagai fumigan, karena bau yang ditimbulkan oleh senyawa metabolit sekunder yang menguap sebagai gas. Pada umumnya senyawa aktif masuk ke dalam tubuh serangga melalui spirakel dan kutikula tubuh. Daya kerja racun menyerang pada sistem saraf pusat dan cepat menimbulkan kelumpuhan (Mattingly, 1986). Menurut Tarumingkeng (1992), senyawa aktif dari metabolit sekunder dapat menyebabkan gerakan serangga yang pasif atau aktif, menurunkan nafsu makan, tidak memberikan respon gerak, dan mati. Kematian $H$. hampei ditandai dengan tubuhnya yang sudah tidak bergerak dan kaki yang kaku saat disentuh dengan kuas. Secara morfologi imago $H$. hampei yang mati perbedaannya tidak begitu terlihat antara kontrol dan perlakuan yaitu warna tubuh yang kehitaman.

Pada penelitian ini, aplikasi ekstrak limbah serbuk gergaji sengon dengan konsentrasi yang semakin tinggi menunjukkan respon kematian serangga uji yang tinggi pula. Hal ini sesuai dengan penelitian Saputra et al., (2013), yang menyatakan bahwa konsentrasi 5 g 1-1, $10 \mathrm{~g}$ $1^{-1}, 15 \mathrm{~g} 1^{-1}$, dan $20 \mathrm{~g} 1^{-1}$ Metarhizium anisoliae yang diaplikasikan pada Helopeltis spp. selama 10 hari menunjukkan adanya peningkatan persentase kematian, yaitu 46,81; 65,19; 73,52; dan 83,82. Hal ini menunjukkan bahwa semakin tinggi konsentrasi ekstrak maka semakin tinggi kematian serangga uji. Hasil penelitian Astriani (2010), menunjukkan bahwa ekstrak tembelekan dan babadotan mampu meningkatkan kematian Sitophillus spp. dengan konsentrasi ekstrak tembelekan dan babadotan yang diaplikasikan yaitu 2\%, 4\%, 
Biotropic 2019 Vol. 3 (1): $39-48$

Toksisitas Ekstrak n-heksana Serbuk Gergaji Kayu Sengon (Albizia falcataria L. Forberg) terhadap Mortalitas Serangga Penggerek Buah Kopi (Hypothenemus hampei Ferr.) (Scolytidae: Coleoptera)

dan 6\%. Konsentrasi ekstrak tembelekan $2 \%$, 4\% menghasilkan persentase kematian sebesar 50\%, dan pada konsentrasi $6 \%$ persentase kematian sebesar 67,5\%. Sedangkan, mortalitas ekstrak babadotan $2 \%$, $4 \%$, dan $6 \%$ menghasilkan persentase kematian sebesar 57,5\%, 80\%, dan 82,5\%. Sari et al., (2013), menyatakan bahwa peningkatan konsentrasi berbanding lurus dengan peningkatan bahan racun, sehingga daya bunuh terhadap serangga semakin tinggi. Menurut Krestini (2011), semakin tinggi konsentrasi maka kandungan senyawa aktif yang terkandung pada ekstrak juga semakin tinggi.

\section{KESIMPULAN}

Ekstrak n-heksana serbuk gergaji $A$. falcataria memiliki efek mortalitas terhadap H. hampei. Ekstrak serbuk gergaji kayu sengon terhadap $H$. hampei dapat menyebabkan kematian lebih dari 90\% pada konsentrasi 4\% pada jam ke-120.

\section{DAFTAR PUSTAKA}

Adirestuti P., Puspadewi R., \& Faramayuda F. 2014. Isolasi Senyawa Metabolit Sekunder dari Daun Sengon (Albizia falcataria (L.) Fosberg.) untuk Antimikroba Topikal. Prosiding Seminar Nasional. Ilmu Pengetahuan dan Teknologi, Universitas Jenderal Achmad Yani.

Aini, E. S. L. 2018. Uji Fitokimia dan Uji Toksisitas Ekstrak Metanol dan Nheksana Kulit Batang Rhizophora mucronata (Lamk.) terhadap Hypothenemus hampei (Ferr.) Skripsi.
Jember: Jurusan Kimia FMIPA Universitas Jember.

Asmaliyah, Sumardi, \& Musyafa. 2010. Uji Toksisitas Ekstrak Daun Nicolaia atropurpurea Val. terhadap Serangga Hama Spodoptera litura Fabricus (Lepidoptera: Noctuidae). Jurnal Penelitian Hutan Tanaman. 7(5): 253 263.

Astriani D. 2010. Pemanfaatan Gulma Babadotan dan Tembelekan dalam Pengendalian Sitophilus spp. pada Benih Jagung. Jurnal Agri Sains. 1(1): 56 $-67$.

Bahri S. \& Rinawati. 2005. Senyawa Terpenoid Hasil dari Daun Lada (Piper nigrum Linn) dan Uji Bioaktivitasnya terhadap Hama Callosobruncus chinensis. Jurnal Sains Tek. 11(3).

Chaib I. 2010. Saponins as Insecticides: A review. Tunisian Journal of Plant Protection, 5(1): 39 - 50.

Dadang \& Prijono D. 2011. Pengembangan Teknologi Formulasi Insektisida Nabati untuk Pengendalian Hama Sayuran dalam Upaya Menghasilkan Produk Sayuran Sehat. Jurnal Ilmu Pertanian. 16(2): 100 - 111.

Francis G., Kerem, Makkar H. P., \& Becker K. 2002. The Biological Action of Saponins in Animal Systems: A review. British Journal of Nutrition, 88, 587-605.

Hussain M. M., Tahia F., \& Rashid M. A. 2016. Secondary Metabolites from Some Species of Albizzia: A Review. Bangladesh Pharmaceutical Journal. 19(1): 1 - 8 .

Hopkins W. G. \& Honer N. P. A. 2004. Introduction to Plant Physiology. Third Edition. John Wiley and Sons, Inc. Ontario.

Irulandi S., Rajendran R, Chinniah C., \& Samuel S. D. 2007. Influence of Weather Factors on the Incidence of Coffee Berry Borer, Hypothenemus hampei 
(Ferrari) (Scolytidae: Coleoptera) in Pulney hills, Tamil Nadu. Madras Agric. J. 94(7-12): $218-231$.

Istimuyasaroh, Hadi M., \& Tarwotjo U. 2009. Mortalitas dan Pertumbuhan Larva Nyamuk Anopheles aconitus karena Pemberian Ekstrak Daun Selasih Oscimum basilicum. BIOMA. 11(2): 59 63.

King M., Catranis C., Soria J. A., \& Leigh M. B. 2013. Phytochemical and Toxicological Analysis of Albizia falcataria Sawdust. International Wood Products Journal. 4(4): 232 - 241.

Krestini, Eti H., Setiawati W., \& Sulastrini L. 2011. Pengaruh Ekstrak Tumbuhan Babadotan (Ageratum conyzoides), Kirinyuh (Eupatorium odoretum), dan Tagetes (Tagetes erecta) terhadap Mortalitas Hama Myzus persicae, Trialeurodes vaporarioum, dan Predator Kumbang Cocci Menochillus sexmaculatus. Semnas Pesnab IV.

Krisnawati H., Varis E., Kallio M., \& Kanninen M. 2011. Paraserianthes falcataria (L.) Nielsen: Ekologi, Silvikultur dan Produktivitas. Bogor: CIFOR.

Liu R., Ma S., Yu S., Pei Y., Z Zhang S., Chen X., \& Zhang J. 2009. Cytotoxic Oleanane Triterpene Saponins from Albizia chinensis. Journal of Natural Products. 72(4).

Mattingly, P. F. 1986. The Biology of Mosquito Borne Disease. New York: Americans Elsivier.

Prijono, D. 1988. Pengujian Insektisida. Bogor: Institut Pertanian Bogor, Fakultas Pertanian, Jurusan Hama dan Penyakit Tumbuhan.

Rastuti, U. \& Purwati. 2012. Uji Aktivitas Antioksidan Daun Kalba (Albizia falcataria) dengan Metode DPPH dan Identifikasi Senyawa Metabolit Sekunder. Program Studi Kimia Fakultas Sains dan Teknik Universitas
Jenderal Soedirman. Jurnal Molekul. $7(1)$.

Rattan, R.S. 2010. Mechanism of Action of Insecticidal Secondary Metabolites of Plant Origin. Crop Protection. 29(9): $913-920$.

Rohmawati, A. 2015. Pengaruh Kombinasi Ekstrak Tembelekan (Lantana camara) dan Babadotan (Ageratum conyzoides) sebagai Pestisida Nabati terhadap Sitophilus oryzae Penyimpanan Beras. Skripsi. Jurusan Biologi Fakultas Sains dan Teknologi Universitas Islam Negeri Maulana Malik Ibrahim Malang.

Saputra, Z., Purnomo, Nur, Y., \& Lestari, W. 2013. Pengaruh Aplikasi Beberapa Konsentrasi Formulasi Kering Metarhizium anisopliae (Metsch.) Sorokin Isolat Tegineneng terhadap Mortalitas Hama Penghisap Buah Kakao (Helopeltis spp.). Jurnal Agrotel Tropika. 1(3): 309 - 314.

Sari M., Lubis L., \& Pangestiningsih Y. 2013. Uji Efektivitas Beberapa Insektisida Nabati untuk Mengendalikan Ulat Grayak (Spodoptera litura) (Lepidoptera: Noctuidae) di Laboratorium. Jurnal Online Agroteknologi. 1(3): 1 - 10.

Schmutterer H. 1999. Properties and Potential of Natural Pesticides: from the Neem Tree Azadirachta indica, Annual Review of Entomolog. (35): 271 $-297$.

Sinha B. 2012. Albizia odoratissima Bark has Insecticidal Activity Against the Cabbage Butterfly Pieris brassicae. Research Paper. Proc Indian natn Sci Acad. 78(2).

Tarumingkeng R. C. 1992. Insektisida: Sifat, Mekanisme Kerja, dan Dampak Penggunaannya. Jakarta: Universitas Kristen Krida Wacana.

Wiryadiputra S. 2012. Keefektifitan Insektisida Cyantraniliprole terhadap 
Biotropic 2019 Vol. 3 (1): $39-48$

Toksisitas Ekstrak n-heksana Serbuk Gergaji Kayu Sengon (Albizia falcataria L. Forberg) terhadap Mortalitas Serangga Penggerek Buah Kopi (Hypothenemus hampei Ferr.) (Scolytidae: Coleoptera)

Hama Penggerek Buah Kopi

(Hypothenemus hampei) pada Kopi Arabika. Pelita Perkebunan. 28(2): 100

$-110$.

Yunita E. A., Nanik H. S., \& Jafron W. H. 2009.

Pengaruh Ekstrak daun Teklan

(Eupatorium riparium) terhadap

Mortalitas dan Perkembangan Larva

Aedes aegypti. Bioma. 11(1): 11 - 17. 